\title{
The problems of access to justice in rural areas (on the example of Ukraine)
}

\author{
Andrii Lapkin* \\ Yaroslav Mudry National Law University, Kharkiv, Ukraine
}

\begin{abstract}
In this scientific article, problems of access to justice in rural areas in Ukraine are considered. It is proved that for the people living in rural areas it is necessary to consider access to justice as possibility of free application to justice system for protection of their rights that is without any obstacles or difficulties. However in need of application to a court the rural dwellers face a lot of problems, such as: territorial, economic and organizational. Territorial problems relate to territorial distance of judicial authorities from rural areas. Economic problems relate to high level of court expenses and low financial well-being of rural dwellers. Organizational problems relate to absence of the necessary infrastructure in rural areas facilitating access to court (lack of transport infrastructure, absence of highspeed Internet and possibility to use technologies of "electronic justice"). The conclusion is that for the solution of this problem it is possible to offer the following steps: general development of infrastructure in rural areas; formation of judicial system on the basis of uniform territorial distribution; reduction of court expenses for dwellers of rural areas proportionally to the level of their incomes; development of institution of lay justice operating in rural areas.
\end{abstract}

Key words: access to justice, human rights, rural areas.

\section{Introduction}

The human right on access to justice is the main guarantee of the right to the judicial protection fixed in the International Covenant on Civil and Political Rights (1966) and the Convention for the Protection of Human Rights and Fundamental Freedoms (1950). Though the right to access to justice is not mentioned in the text of these acts directly, it is considered as a necessary component of the right to fair judicial proceedings. Originally in decisions of the European Court on Human Rights this right was allocated proceeding from the need to guarantee human rights not only during participation in already begun trial, but also concerning a reference to the court for protection of the rights. In further practice of the European Court on Human Rights the issues of refusal in access to justice or making of excessive financial or procedural difficulties to its realization were considered. These are cases "Golder v. the United Kingdom" [1], "Airey v. Ireland" [2] and others.

Especially relevant ensuring the right to access to justice is for the people living in rural areas. Ukraine is characterized by high specific weight of rural population in the general structure of the population of the country. At the beginning of 2019 in Ukraine over $30 \%$ of the population of the country, that is more than 14 million people, lived in rural areas [3]. However processes of urbanization and sharp falling of a standard of living in rural areas

\footnotetext{
* Corresponding author: an.lapkin@gmail.com
}

(C) The Authors, published by EDP Sciences. This is an Open Access article distributed under the terms of the Creative Commons Attribution License 4.0 (http://creativecommons.org/licenses/by/4.0/). 
in the last decades lead to reduction of number of rural dwellers. Especially it concerns a young and able-bodied part of rural population. At the same time the level of violation of the rights of inhabitants of rural areas is rather high and level of their legal literacy - very low. In rural areas, often there are no authorities to whom people could address for protection of the rights. There are also no mechanisms of the alternative solution of the conflicts, available in the cities. As a result of this, violations of the rights of inhabitants of rural areas often have no legal consequences. Thus, the considerable part of the population of Ukraine, living in rural areas, is especially vulnerable concerning the issues of legal protection, therefore its specifics demands creation of additional guarantees of access to justice.

\section{Aim}

The purpose of this scientific research is allocation and classification of problems which rural population faces at access to justice. It is also necessary to offer the ways of overcoming these problems for improvement of availability of justice to inhabitants of the rural areas.

\section{Material and methods}

The scientific research is based on theoretical works of scientists who have considered problems of availability of justice, for example: M.A. Gurvich, I.E. Marochkin, E.N. Ovcharenko, N.Yu. Sakara, N.V. Sibileva, Yu.I. Stetsovsky and others. The empirical material consisted of statistical information of authorities of Ukraine, materials of court practice and own experience of the author's life in the rural area. In the course of the research the dialectic method and also a comparative method, methods of analysis and synthesis, a method of law modelling and others were used.

\section{Results and discussion}

Access to justice is defined as the ability of people to seek and obtain a remedy through formal or informal institutions of justice for grievances in compliance with human rights standards. There is no access to justice where citizens (especially marginalized groups) fear the system, see it as alien, and do not access it; where the justice system is financially inaccessible; where individuals have no lawyers; where they do not have information or knowledge of rights; or where there is a weak justice system [4]. In the Declaration of the high-level meeting of the General Assembly on the rule of law at the national and international levels adopted by the General Assembly in Resolution on 24 September 2012 it was underlined: "We emphasize the right of equal access to justice for all, including members of vulnerable groups, and the importance of awareness-raising concerning legal rights, and in this regard we commit to taking all necessary steps to provide fair, transparent, effective, non-discriminatory and accountable services that promote access to justice for all, including legal aid" [5, point 14].

It is possible to define access to justice as free possibility to use the right to judicial protection, lack of any obstacles at a reference to the court. In scientific legal literature access to justice is considered and as access to court, and as access to the judge, and as access to judicial authority as a whole. In our opinion, it is necessary to apply the widest meaning to the characteristic of this concept. Proceeding from it, for the people living in rural areas, it is necessary to consider access to justice as possibility of free appeal to justice system for protection of their rights. In a broad sense access to justice includes as possibility of address directly in a court, and to bar and prosecutor's office, bodies of execution of judgments.

At the heart of availability of justice the possibility of appeal to a court without any obstacles or difficulties lies. 
Thus, guarantees of availability of justice provide, first of all, elimination or minimization of obstacles for appeal to a court. There is a direct dependence: the fewer obstacles lie in the way to a court (or the less they are expressed), the more available justice is. However in the need of appeal to a court the people living in rural areas face a number of problems. These problems are in many aspects different from the problems arising in the sphere of access of urban population to justice. On the basis of their analysis it is possible to allocate such problems of access to a court of rural population: the territorial; the economic; the organizational.

\subsection{Territorial problems}

Territorial problems consist in a territorial distance of judicial authorities from rural areas. So, today courts of the first instance function in Ukraine on the level of the cities and districts.

Existence of the local court in each district centre is convenient for a rural population. Regardless of the fact that the distance from some villages to the district centres can make 30-50 kilometres, in most cases within the district continuous transport connection is adjusted. Generally it is carried out by buses and also, in the presence of the railroad - by means of trains or electric trains (that represents the most budgetary option). A district centre in which a court is situated is also the centre of municipal authorities, a solicitor, etc., thus the villager can receive legal and administrative service, having arrived there.

However judicial reform provides creation of district courts which will act on the level of several districts. The law of Ukraine "On the Judicial System and the Status of Judges" of June 02,2016 provides that instead of district and city courts country courts will operate on the local level [6]. In Ukraine, within the reforms, instead of 663 local general courts it is planned to create about 270 new country courts. The process of reorganization of local general courts in the country began in 2018 and should be completed in 2019. Thus, the number of local courts will be reduced by 2.5 times though the number of judges, who work in them, is planned to remain the same. One court will cover several areas. This would entail territorial distance of the court from the population of rural area, since it would be much more difficult for the population of other areas covered by its jurisdiction to reach it. It will cause territorial distancing of a court from the population of rural area. To the population of other areas it will be much more difficult to reach the court than of the areas where there is the court.

A similar reform was carried out concerning prosecutor's office. As a result authority of local prosecutor's offices extends to on the average 5-7 districts in rural areas. At the same time the distance between these districts and the main office of local prosecutor's office may be more than 100 kilometres. Between many districts falling under territorial jurisdiction of local prosecutor's office, there is no direct transport service. It means that to reach the prosecutor's office, the inhabitant of rural areas has to travel to the regional centre (for 100-200 kilometres), and from there - to the locality where the prosecutor's office is situated [7]. At the same time it is necessary to consider that population appeal to the prosecutor's office considerably less than in the court. That is the territorial remoteness of court from a rural population is more critical than remoteness of prosecutor's office.

Application of this principle to the local courts will lead to the fact that rural population is far away from judicial authorities. It roughly breaks requirements of territorial availability of justice. In this regard it is necessary to consider recommendations according to which within a district centre of an oblast premises of courts should be located in an administrative centre. It has to be near other premises of authorities, local governments, main enterprises, institutions and organizations. Considering absence of public transport in many cities of district significance this situation acquires special relevance [8]. 
Considering the reasons for such reform, its creators first of all refer to the need of economy. It is considered that the provision of smaller number of larger courts is economically more beneficial for the state than the maintenance of bigger number of smaller ones. However, if we analyze the experience of the reform of the prosecutor's office in Ukraine, we can conclude that no savings were achieved. Difficulties in placement of local prosecutor's offices led to the placement of their departments in geographically remote locations. Earlier, district prosecutor's offices functioned there, which were liquidated as a result of the reform. However, the presence of departments requires premises, staff and support staff that had operated there before. Consequently, the reform of the prosecutor's office was in many ways fictitious and did not justify hopes of saving.

It can be predicted that the reform of the local courts will be completed in this way. The need for access to justice of local population will entail creation of court departments in remote locations. They reanimate the local courts that existed there. This may solve the problem of territorial remoteness, but will sacrifice economic expediency. Otherwise, the savings from reduction of local courts, which the state will achieve, will actually be transferred to the budget of rural residents, because they will have to spend much more money to get to a remote court to participate in court proceedings.

A perspective option for solving the problem of territorial remoteness of courts from rural population is creation of magistrate's courts. The experience of their existence took place in Ukraine in the period after the Judicial Reform of 1864. According to Ukrainian researchers, the institute of lay justice makes it easier for people to access justice and relieve local courts. It is also able to speed up consideration of cases by courts and increase public confidence in the judiciary [9]. At the same time, experts point out such problems of lay justice as search for ways to finance it; determination of a network of magistrate courts; their staffing; jurisdiction of the magistrate courts; procedure for appealing their decisions, etc. [10].

These provisions can be applied to rural population. Magistrate's courts, as alternative ways of resolving conflicts, are effective and cheap means of increasing accessibility of justice in rural areas. In the conditions of territorial remoteness of official courts, lay courts are able to quickly resolve minor civil and criminal cases on the ground. Therefore, the issue of creating of magistrate's court in rural areas is perspective for Ukraine.

\subsection{Economic problems}

The economic aspect of access to justice includes the reasonableness of court costs for participants in court proceedings, as well as adequate funding for the judiciary. According to scientists, the economic components of accessibility of justice are: 1) the reasonableness of court costs and creation of a procedural mechanism for postponing, instalment or exemption from court costs; 2) provision of qualified legal assistance on preferential conditions to indigent persons; reasonableness of expenses for representative services; 3) adequate financing of judicial activities, ensuring the possibility of full and independent justice [11]. In the economic aspect, there are a number of limitations in access to justice for rural dwellers.

Economic problems consist in high level of court costs and low financial well-being of rural inhabitants. In comparison with cities, the average level of incomes in rural areas is much lower. So, the average salary in agriculture in Ukraine following the results of 2018 was 7129 UAH (about 222 Euros) that is below the average salary in the country (8711 UAH or about 272 Euros), as well as that which is fixed in other types of economic activity: in industry (9458 UAH or about 295 Euros), transport sphere (9787 UAH or about 306 Euros), financial activity (15986 UAH or about 500 Euros) and others [12]. Also in rural areas unemployment rate is much higher. So, according to the data at the end of 2018 , the number of unemployed 
urban residents was 183.2 thousand, and the number of rural residents -158.5 thousand [13] (despite the fact that rural residents, as mentioned earlier, make up one third of the population of Ukraine). Thus, the incomes of rural inhabitants are much lower than the urban ones. In addition, unemployment is much higher in rural areas, which aggravates the economic problems of rural population.

However the level of court costs is identical to all and does not consider a difference in incomes of people who are appealing to a court. According to Part 1 of the Art. 4 of the Law of Ukraine "On Court Fee", court fee is set as a percentage of the price of a claim or in a fixed amount. The fixed amount of court fee is set according to the size of the subsistence minimum for able-bodied persons, established by law on January 1 of the calendar year in which the corresponding statement or complaint was filed [14]. The minimum court fee for filing a claim in a court for individuals is 0.4 of the size of the subsistence minimum for able-bodied persons. Since January 1, 2019, the minimum of this amount is 1921 UAH (60 Euros) and the minimum court fee is $768.4 \mathrm{UAH}$ (24 Euros). This amount is palpable for rural residents and limits their ability to go to court to protect their rights.

Moreover, villagers initially incur higher expenses connected with the need of trip to the city in which a court is located. Due to the frequent postponement of the proceedings in a court and the length of the process, the villager has to visit the court a lot of times. In the conditions of high prices for transport, trips to the court are burdensome. At the same time, the court does not warn the participants of the trial about transfer of the case in advance; therefore, they can learn about it only by appearing directly to a court. The legislation does not provide any compensation for the cost of travel to the court in cases where the process was postponed due to the fault of a court or for other reasons that do not depend on honest participants in the process, who appeared in the court.

Also expensive for residents of rural areas are the services of lawyers. Prices for them in Ukraine are about the same in cities and in rural areas. However, due to lower incomes of rural residents, cost of services of lawyers is often inaccessible to them. They also spend more for payment of the help of lawyers which put transportation costs in the fee. In many rural areas there are no resident lawyers. Therefore, there is a need to involve lawyers from major cities, and, accordingly, to pay for their arrival in a court.

In Ukraine, the centres for the provision of free secondary legal aid, which are being created in each district, are designed to solve this problem. The state hires lawyers to work in such centres and pays for their services from the state budget. These centres operate on the basis of the Law of Ukraine "On Free Civil Legal Aid" from June 2, 2011 [14]. In accordance with this law, the right to get a lawyer at the expense of the state have among different categories of citizens as well low-income citizens. However such centres do not provide with free legal aid of everyone today. Besides, the quality of the services provided by the centres is low as lawyers who work there, are not interested in high quality of legal services.

Thus, justice is excessively expensive for the majority of rural dwellers. In this regard, rural residents are trying to avoid participation in trials because of their high cost. Thus, they voluntarily deprive themselves of judicial protection. To overcome this negative trend, it is necessary to make justice cheaper for rural residents in order to take into account their low incomes.

\subsection{Organizational problems}

Organizational problems cover a wide range of issues related to creation of appropriate conditions for going to the court and obtaining judicial protection. 
Organizational problems in rural areas consist in absence of necessary infrastructure facilitating access to a court. First of all, that is lack of transport infrastructure whereupon people experience difficulties to reach the court. We have already dealt with this problem above in the aspect of the territorial remoteness of courts from population. Transportation costs are expensive for rural residents and are constantly rising. Only a small part of rural population in Ukraine has a personal vehicle. Therefore, villagers are forced to use public transport to get to a court. At the same time, in many Ukrainian villages there are no normal roads and there are interruptions in transport, in this aspect a trip to a court becomes a long and difficult. In winter, the roads to remote villages are not cleared of snow and it is almost impossible to get there. The public transport schedule does not fully coincide with the court's work schedule (for example, there is no traffic until 9:00 am or after 5:00 pm, whereas at that time cases are scheduled in a court).

The solution of the problem of territorial remoteness of courts could be using of modern information technologies in the field of justice. The possibility of remote participation in consideration of cases by courts is provided for by the procedural legislation of Ukraine. However, it is used only in exceptional cases. For example, in criminal proceedings court proceedings may be conducted through video conference with transmission from another premise, including such as is located beyond the bounds of the court premises, where 1) it is impossible for a participant of criminal proceedings to participate directly in the court proceedings for reason of health or for other valid reasons; 2) it is necessary to ensure the persons' security; 3) a minor or underage person is to be interrogated as a witness or victim; 4) such measures are necessary to ensure speedy court proceedings; 5) there exist other grounds recognized sufficient by the court. At the same time, a bailiff or a secretary of court session of the relevant court is obliged to hand such person a memorandum of his procedural rights, check his identity documents, and be with him until the end of the court session (Art. 336 of the Criminal Procedure Code of Ukraine) [16].

In a civil proceeding, participation in a court hearing via videoconference is simpler. In accordance with the Article 212 of the Civil Procedure Code of Ukraine [17], participants in a case may participate in a court hearing in the videoconference mode in the presence at court of the corresponding technical capability. For this purpose it is necessary to submit the application no later than five days before judicial session. The participants in the case take part in the court session in the videoconference mode with use of own technical means and the digital signature.

It is obvious that use of the mode of a videoconference would reduce costs of villagers of personal participation in lawsuits. As experts note, use during judicial sessions of systems of a videoconferencing will in most cases avoid delaying the court hearing of a case due to the fact that a particular participant of the process cannot appear at the court session. The efficiency of systems of a videoconferencing in the course of hearing of cases in a court is proved by experience of their application in foreign countries. Also their use will allow to citizens to save considerable sum of money necessary for trips to courts which are located in other settlements [18].

However, in a lot of villages of Ukraine there is no high-speed Internet in this connection their population is deprived of possibility to use technologies of "electronic justice". Besides, most of villagers (as well as in general residents of Ukraine) has no digital signature that does not allow them to use remote participation in lawsuit. The practice of using the videoconference mode by the courts in Ukraine is not widespread, and judges treat it with mistrust. In addition, in order to initiate the issue of participation in a court session via videoconference, a person must submit a relevant application to the court in advance, for what it needs to be personally in court. Therefore, the practice of remote participation in 
court sessions in Ukraine requires improvement. Its positive impact on access to justice for rural residents requires, on the one hand, the development of information technologies in rural areas, and on the other, the development of electronic justice, which level in Ukraine lags far behind other countries.

Organizational problems of access to justice are also shown by the fact that for an inhabitant of rural areas it is much more difficult to find the lawyer to receive a legal aid. Villagers have deficiency of information on lawyers who work in their area as do not use the Internet. A lot of lawyers, proceeding from low solvency of rural population and transport remoteness, do not consider rural dwellers as clients. The lawyers who work in the rural zone often have low professional level due to the lack of the competition. Personal contacts with lawyers also are inconvenient. For a meeting with a lawyer villagers are forced to overcome the same, and sometimes a bigger distance, than for a visit to a court. In the conditions of deficiency of personal contact it is difficult to lawyer to estimate a legal position of the client correctly. In turn, it is difficult to a client to determine the level of professional competence of the lawyer which they address. Therefore the villager experiences much more organizational difficulties in access to justice, than city inhabitant.

It is necessary to consider that organizational problems concern not only inhabitants of the rural zone, but also judges who work there. Today in many courts in Ukraine there is an acute issue of understaffing. So, in Ukraine at the end of 2016 there were more than 200 courts (about a third of the total) in which more than a half of judges did not work. The reasons of such situation are different: expiration of the term of office of a judge, untimely swearing in of a judge, achievement by a judge of 65 years and others. Basically, these problems concern the courts located in rural areas, since the work in them is considered less prestigious for judges. Courts operating in rural areas often lack premises suitable for implementation of justice. There are problems with heating of the premises of courts and sewage. In the rural areas housing is not under construction; therefore, the appointed judges cannot receive the room for accommodation there. The lack of jobs, kindergartens and schools creates problems for family members of judges working in rural areas. Thus, the majority of judges do not want to work in courts located in rural areas. They consider the work in such courts as an intermediate option and as soon as possible they try to transfer to the courts located in cities. On the other hand, judges with the lowest positions in the ranking get to work in courts located in rural areas, which lowers professionalism level at implementation of justice in the rural areas.

\section{Conclusions}

Generally, it should be noted that the people living in rural areas, face a number of additional obstacles at a reference to a court, than city dwellers therefore their access to justice is actually limited. For the solution of this problem it is possible to offer the following steps:

1) General development of infrastructure in rural areas. The more economically the village is developed - the more available justice becomes for his inhabitants. Increase of welfare of inhabitants of rural areas will give the chance to them to protect their rights more effectively. Modern roads, reliable public transport, the high-speed Internet are necessary for access to justice in rural areas.

2) Creation of judicial system on the basis of uniform territorial distribution. Defining the centres of judicial districts it is necessary to consider distance for the most remote villages which, in our opinion, should not exceed 30 kilometres. Also in courts there should be enough judges to consider cases quickly and effectively.

3) Introduction of modern information technologies. It is necessary to provide possibility of remote participation in trial for inhabitants of remote settlements. The submission 
of documents in the court in an electronic form is expedient. The reliable system of informing on carrying out a court session and about its cancellation or postpone is also necessary.

4) Reduction of court costs for inhabitants of rural areas. It could be reached by calculation of the level of judicial taxes in proportion to the level of incomes of participants of process. Expansion of the system of free legal aid and its introduction in rural areas also is required. The inhabitants of rural areas being participants of the trial should obtain compensation of the transportation costs connected with a call in court.

5) Provision of villagers with the qualified legal aid. In cases of insolvency of a client such help has to be provided at the expense of the state. It can be reached by development of the centres of free secondary legal aid which are created in Ukraine. Lawyers should be interested in quality of the legal services provided by them. For this purpose it is expedient to put the size of their fee into dependence on results of consideration of a case.

6) Development of the institute of lay justice in rural areas. Possibility of solution of simple disputes by lay judges directly on the place of contract of their parties will approach justice to rural areas. Also it will simplify the trial and will reduce its terms. Another positive effect is that it will be possible to unload judicial system and to lower load of professional judges.

\section{References}

[1] European Court of Human Rights judgment in case Golder v. the United Kingdom, 4451/70, 21.02.1975 URL: http://hudoc.echr.coe.int/app/conversion/ pdf $/$ ? library=ECHR\&id=001-57496\&f ilename=001-57496.$p d f$

[2] European Court of Human Rights judgment in case Airey v. Ireland, 6289/73, 09.10. 1979 URL: https://ww3. lawschool. cornell.edu/AvonResources/Airey. PDF

[3] Населення Украӥни на 2018 рік. URL: https://ukrainatoday.com. ua/naselennya-ukra\%D1\%97ni-na-2018-rik/

[4] Necessary Condition: Access to Justice. URL: https://www.usip.org/guidingprinciples-stabilization-and-reconstruction-the-web-version/rulelaw/access-justice

[5] Declaration of the high-level meeting of the General Assembly on the rule of law at the national and international levels: Resolution adopted by the General Assembly on 24.09.2012. URL: https://undocs.org/en/A/RES/67/1

[6] Про судоустрій $i$ cmamyс суддів: Закон України від 02.06.2016. URL: http: //zakon3.rada.gov .ua/laws/show/1402-19

[7] Лапкін А.В. Закон Украӥни «Про прокуратуру». Науково-практичний коментар. Харків: Право, 26 (2015)

[8] Овчаренко О.М. Доступнйстї правосуддя та гарантіы його реалізаціы: Монографія. Харків: Право, 86 (2008)

[9] Цибуляк-Кустевич А.С. Мирова юстиція: дисертація ... канд. юрид. наук: 12.00 .10. Харків, 72 (2016)

[10] Дем'аненко. В. Організачійно-правові основи діяльності місчевих загальних судів в Україні: дисертація ... канд. юрид. наук: 12.00.10. Харків, 140 (2017)

[11] Сидоренко B.М. Приниип доступности правосудия и проблемы его реализачии в гражданском и арбитражном процессе: диссертация ... канд. юрид. наук: 12.00.15. Екатеринбург, 8 (2002) 
[12] Середньомісячна заробітна плата за видами економічної діяльності за період з початку року у 2018 рочі. URL: http: //www . ukrstat.gov .ua/

[13] Кількість зареєстрованих безробітних за статтю та місцем проживання y 2018 poui. URL: http: //www. ukrstat.gov.ua/

[14] Про судовиі збір: Закон України від 08.07.2011. URL: https://zakon.rada.gov.ua/laws/show/3674-17

[15] Про безоплатну правову допомогу: Закон України від 02.06.2011. URL: https://zakon.rada.gov.ua/laws/show/3460-17

[16] Кримінальний прочесуальний кодекс Украйни від 13.04.2012. URL: http://zakon2.rada.gov.ua/laws/main/t21

[17] Цивільний прочесуальний кодекс Украйни від 18.03.2004. URL: https://zakon.rada.gov.ua/laws/show/1618-15

[18] Відеоконференція - крок у майбутне. URL: https://zib.com.ua/ua/ print/49182-videokonferenciya__krok_u_maybutne.html 